\title{
Biostratigraphy of the Late Middle Pleistocene (Middle Neopleistocene) of the Southern Urals region
}

\author{
Guzel A. Danukalova*, Anatoly G. Yakovlev, Eugenya M. Morozova, Liliana I. Alimbekova \\ Institute of Geology, Ufa Scientific Centre, Russian Academy of Sciences, K. Marx Street, 16/2, 450000, Ufa-centre, Bashkortostan, Russia
}

Available online 17 November 2006

\begin{abstract}
A summary of published and unpublished materials on the stratigraphy of the Late Middle Pleistocene (Middle Neopleistocene according to the Russian stratigraphic scheme) of the Southern Urals region is given. Deposits of different origin in the regional stratigraphic units are characterized. The results of mammalian investigations provide the basis for the stratigraphical subdivision. Mollusca and palynology are used for the reconstruction of the palaeoenvironments. The stratigraphical positions of the main Middle Neopleistocene localities and precise definitions of the stratigraphical scheme of the Southern Urals region are discussed. The Southern Urals subdivisions are correlated with the Western European stratigraphical schemes (Holsteinian-Saalian interval).

(C) 2006 Elsevier Ltd and INQUA. All rights reserved.
\end{abstract}

\section{Introduction}

During the Quaternary, the Southern Urals region is characterized by continental conditions and by slow tectonic activity. During the periods of cold climate, the region was a non-glacial area. Local permafrost basins existed on the plain, whilst small corrie glaciers formed in the mountains. Fluvial deposits are the main subjects of the palaeogeographical reconstructions and for the correlation of varying sediment units. These deposits characteristically occur in considerable thicknesses and contain organic remains. Deposits dating from the Middle Neopleistocene (a unit of the Russian stratigraphic scheme, equivalent to the late Middle Pleistocene subseries; time interval $0.43-0.135 \mathrm{Ma})$ are preserved in the local region. The systematic study of the Neopleistocene deposits of the Southern Urals region has been carried out for over 50 years. Over 18 key localities, that expose Middle Neopleistocene deposits, are described, four of which contain mammalian fossils. All these sites are located in the Belaya River valley in the terraces above the modern floodplain (Fig. 1).

\footnotetext{
${ }^{*}$ Corresponding author.

E-mail address: danukalova@anrb.ru (G.A. Danukalova).
}

\section{Materials}

Middle Neopleistocene deposits have been investigated and described from 18 sites. Sixteen key sections have been studied palaeobotanically (nearly 170 samples in total). Four of these localities have yielded mammalian fossils (over 4000 identifiable small-mammal remains). Five sites contain preserved ostracod shells (1944 identifiable specimens), and eight localities contain mollusc shells (nearly 758 mollusc shells or their identifiable fragments).

The mammal localities have yielded 10 species and 9 genera from the Belaya Horizon (equivalent to the Holsteinian Stage interval, Table 1), 17 species and 13 genera from a second warm interval and 13 species and 12 genera from the cooling in the middle of the Klimovka Horizon (Tables 1 and 5). Mollusc sites have yielded 29 species and 18 named genera from the Belaya Horizon, 3 species and 3 genera from the Larevka Horizon, 25 species and 19 genera from the Klimovka Horizon, and 14 species and 11 genera from the Elovka Horizon (Tables 1 and 4). The ostracod localities have yielded 40 species and 16 genera from the Belaya Horizon and 30 species and 11 named genera from the Larevka Horizon and 13 species and 6 named genera from the Klimovka Horizon and 20 species and 10 named genera from the Elovka Horizon (Tables 1 and 3). 


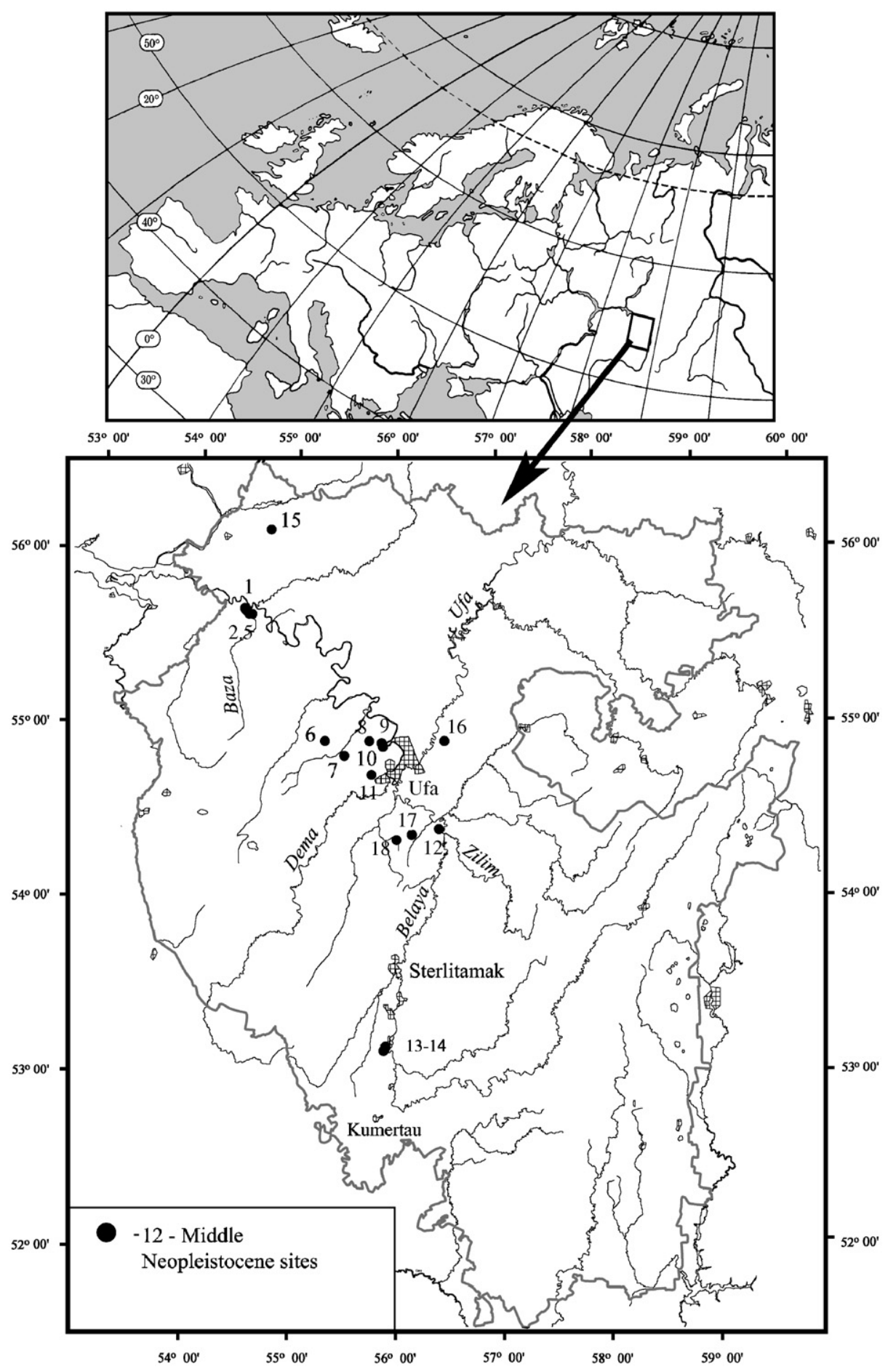

Fig. 1. Map of the studied area and key Middle Neopleistocene sites. Legend: 1-Gruzdevka; 2-5 - Chui-Atasevo I, II, III, V; 6-Starye Tukmakly; 7Sultanaevo; 8-Gurovka; 9-10-Gornova II, III; 11-Voevodskoe; 12-Krasnyi Yar; 13-14—Klimovka II, III; 15-Starokudashevo; 16-Minzitarovo; 17-Chatra; 18 - Ilenka III.

\section{Methods}

Traditional methods of dispersal of sediments in water, using of sieves (mesh size $0.8-1.0 \mathrm{~mm}$ ), were used to recover the small-mammal and molluscan material (Zhadin, 1952; Agadjanian, 1987) and for the separation of plant remains (Guslitcer, 1979; Sinitskikh, 1982). Freshwater molluscs were identified following Zhadin (1952) and Gittenberger and Janssen (1998), and terrestrial molluscs were identified following Likharev and Rammelmeier (1952), Shileiko (1978, 1984), Shileiko and Likharev (1986), and Kerney and Cameron (1999). The large mammals were described according to Gromov and Baranova (1981), and the small mammals were described following Gromov and Erbaeva 
Table 1

Stratigraphic scheme of the Middle Neopleistocene of the Southern Urals region and correlation with schemes of other regions

\begin{tabular}{|c|c|c|c|c|c|c|c|c|c|c|c|}
\hline $\begin{array}{l}\text { Global } \\
\text { Quaternary } \\
\text { scheme } \\
\text { Gibbard et al. } \\
(2004)\end{array}$ & & $\begin{array}{l}\text { Russia } \\
\text { Zhamoida } \\
\text { et al. (2000) }\end{array}$ & & $\begin{array}{l}\text { Southern Urals } \\
\text { region } \\
\text { Yakchemovitch } \\
\text { et al. } \\
\text { (1987, 1988) } \\
\text { with } \\
\text { authors' } \\
\text { corrections }\end{array}$ & $\begin{array}{l}\text { Eastern } \\
\text { European } \\
\text { Platform } \\
\text { Shik (2004) }\end{array}$ & & $\begin{array}{l}\text { Central } \\
\text { regions of } \\
\text { the Eastern } \\
\text { European } \\
\text { Platform } \\
\text { Shik } \\
\text { et al. (2002) }\end{array}$ & $\begin{array}{l}\text { Lower } \\
\text { Volga } \\
\text { region } \\
\text { Shik et al. } \\
(2002)\end{array}$ & $\begin{array}{l}\text { Urals } \\
\text { Stefanovsky } \\
(1997)\end{array}$ & & $\begin{array}{l}\text { West European } \\
\text { stratigraphic } \\
\text { divisions (The Netherlands) } \\
\text { Turner (1998) }\end{array}$ \\
\hline System Series & $\begin{array}{l}\text { Subseries, } \\
\text { Stages }\end{array}$ & Division & Link & Horizon & SuperHorizon & Horizon & Horizon & SuperHorizon/Horizon & SuperHorizon & Horizon & Stage \\
\hline \multirow[t]{5}{*}{ Quaternary Pleistocene } & $\begin{array}{l}\text { Middle } \\
\text { (Upper part) }\end{array}$ & Neopleistocene & Middle & Elovka & $\begin{array}{l}\text { Central } \\
\text { Russian } \\
\text { Plain }\end{array}$ & Moscow & Moscow & Lower Chozar & Middle Urals & Leplinsky & Drenthe glaciation \\
\hline & & & & & & & & & & & $\begin{array}{l}\text { Cold } \\
\text { Interval } \\
\text { with } \\
\text { permafrost }\end{array}$ \\
\hline & & & & Klimovka & & Gorkinsky & Chekalin & & & Nicinsky & $\begin{array}{l}\text { Bantega Interstadial } \\
\text { Cold } \\
\text { interval } \\
\text { Hoogeveen } \\
\text { Interstadial }\end{array}$ \\
\hline & & & & Larevka & & Kaluga & Kaluga & & & Vilgortovsky & $\begin{array}{l}\text { Cold interval } \\
\text { with permafrost }\end{array}$ \\
\hline & & & & Belaya & & Likhvin & Likhvin & Singil & & Sylvitcky & $\begin{array}{l}\text { Holsteinian } \\
\text { Interglacial }\end{array}$ \\
\hline
\end{tabular}


(1995). The principal morphotypes of M1 of Lagurus lagurus and Microtus gregalis were distinguished after Smirnov et al. (1990) and Rekovets (1994) with some changes. Processing of samples for palynological analyses followed the standard methods described by Grichuk and Zaklinskaya (1948) and Pokrovskaja (1950).

\section{Stratigraphical subdivision of the Middle Neopleistocene deposits and their correlation}

Middle Neopleistocene units occur in alluvial and subaerial deposits in the Southern Fore-Urals region. Here, the subdivisions have local names and comprise the Middle Link of the regional stratigraphic scheme, in which the following horizons have been recognized: Belaya, Larevka, Klimovka and Yelovka. These units have been determined on the basis of their mammalian assemblages and they have been correlated with the Middle Pleistocene HolsteinianSaalian stage interval in the western European timescale (Table 1). Correlation of Southern Urals and Eastern European faunas is shown in the Table 2.

\subsection{Belaya Horizon}

This horizon was distinguished and described by V.L. Yakchemovich in 1983. V.L. Yakchemovich, G.A. Danukalova and A.G. Yakovlev described these deposits from the stratotype section in 1983-1985. It is named after the Belaya River (Southern Fore-Urals, Bashkortostan Republic).

The Horizon is characterised by fluvial gravel, gravel with boulders and sand, lacustrine loam, clay and silt, subaerial loam with traces of palaeosols, including the first Chui-Atasevo soil (Chui-Atasevo III, $1 \mathrm{~m}$ thick), the first Sultanaevo soil (Sultanaevo, borehole 1, $0.7 \mathrm{~m}$ thick). The total thickness of these deposits is $1-3.9 \mathrm{~m}$ (average $2.45 \mathrm{~m}$ ) and the maximum thickness is $18 \mathrm{~m}$ at Gurovka. The deposits rest on the eroded surfaces of Lower Neopleistocene (Early Middle Pleistocene), Eopleistocene (Early Pleistocene) and Permian sediments and are overlain by loam of the Larevka Horizon or by fluvial deposits of the Klimovka Horizon and loam of the Elovka Horizon with erosional intervals between them.

The key sites for the Belaya Horizon include fluvial deposits of the over-deepened valley of the Belaya River, near the city of Ufa, and of its tributaries; at sites including Starye Tukmakly; Gurovka; Gruzdevka, Krasnyi Yar; Chui-Atasevo I, II, III, V; Klimovka II, III; Sultanaevo (borehole 1, bore pit 1); Gornova II, III; Voevodskoe; Minzitarovo; Chatra; Ilenka III; Starokudashevo. Stratotype site: Gornova II (beds 25-32), and Gornova III (beds 4, 5) (Yakchemovich et al., 1981, pp. 54-55, 1987, pp. 29-30; 1988, pp. 13-17; Danukalova et al., 2002, pp. 29-31). The parastratotype site for this unit is the Sultanaevo, borehole 1 (beds 7-12), bore pit 1 (beds 11-16) (Yakchemovich et al., 1983, p. 17, pp. 22-24, 40-41; 1988, pp. 15-17).
The ostracods recovered from these localities consist of 40 species and 16 genera (1303 determined specimens). Popova-Lvova (1988) described ostracods from sites Gornova II (206 specimens) (Yakchemovich et al., 1983, 1985; Danukalova et al., 2002), Gornova III (499 specimens), Sultanaevo, borehole 1 and bore pit 1 (583 specimens), Chui-Atasevo I and V (12 specimens), and Minzitarovo ( 3 shells). The rich assemblage consists of freshwater lacustrine species (Table 3), including Limnocythere postconcava, L. manjtschensis, Denticulocythere dorsotuberculata and D. caspiensis which occurred only in the Middle Neopleistocene deposits in the region.

The molluscan assemblages recovered from the Belaya unit consist of 29 species and 18 genera (514 determined specimens) (Table 4). A warm assemblage of freshwater and terrestrial molluses (205 specimens) was found and determined by G.A. Danukalova and E.M. Morozova from the localities Gornova II and III. The 49 specimens recovered from the Sultanaevo site are those that typify flowing and stagnant waters (Yakchemovich et al., 1983; Sydnev, 1988). Lacustrine Mollusca from the Klimovka III site are represented by 90 specimens, lacustrine and terrestral taxa from the Gruzdevka site by 19 specimens (identified by E.M. Morozova). Sydnev (1988) determined 147 shells from the Gurovka locality. From Chui-Atasevo V 2 shells of Dreissena sp. and Lythoglyphus sp. have been recovered, and from Voevodskoe rare small Succinea sp. are known.

The Gornova large-mammal assemblage includes six species and five genera. E.A. Vangengeim (Yakchemovich et al., 1987) described Mammuthus chosaricus Dub. from this site. B.S. Kozhamkulova (Danukalova et al., 2002) described Bison priscus gigas Boj., Bison sp., E. caballus fossilis, Equus sp., Camelus sp., Mammuthus sp. V.E. Garutt (Yakchemovich et al., 1983) determined the remains of Mammuthus chosaricus from the Sultanaevo site. Remains of M. chosaricus, Bison sp., Cervus sp. and wild horse were identified by V.E. Garutt (Shokurov, 1977) from the Starye Tukmakly locality.

The small-mammal assemblage from the Belaya Horizon sediments includes of four species and four genera $(8$ determined specimens). They were found and identified by A.G. Yakovlev (Danukalova et al., 2002) from the Gornova III site. Over one tonne of sediments was washed but mammalian remains were rare, but they included Clethrionomys sp. (1), Lagurus sp. (1), Eolagurus sp. (1), Microtus oeconomus (1) and Microtus sp. (4).

The very common plant macrofossil remains at the Gornova III site were identified by P.I. Dorofeev (Danukalova et al., 2002) as possibly of the Singil or Chozar floras (Table 1). The vegetation that occurred during the deposition of this unit was characterised by herb steppe with rare coniferous-birch-broad-leaves forests at the beginning of the period. The latter probably grew in river valleys. However, the role of forests increased during the second part of the time. At other localities, spore and pollen remains are not numerous but include Picea, Pinus, 
Table 2

Correlation of the Southern Urals and the Eastern European mammal faunas

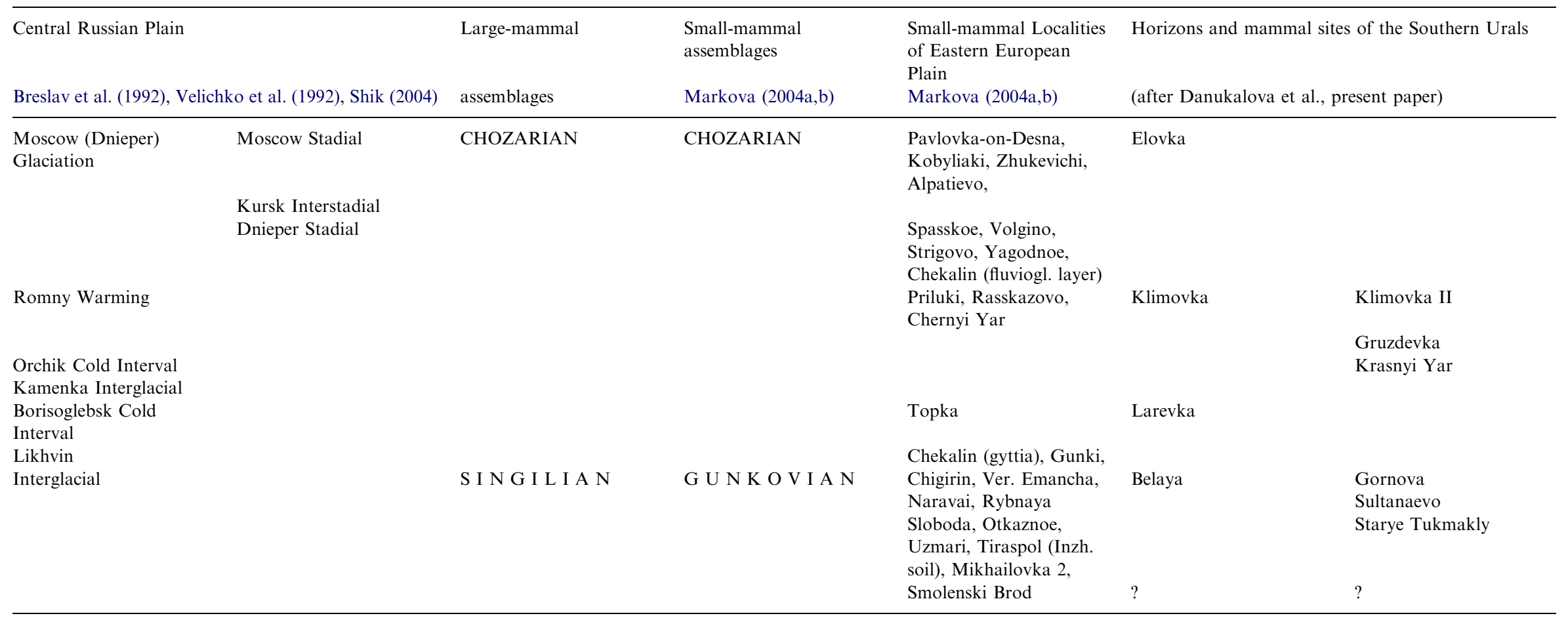


Table 3

Ostracods from the Middle Neopleistocene deposits

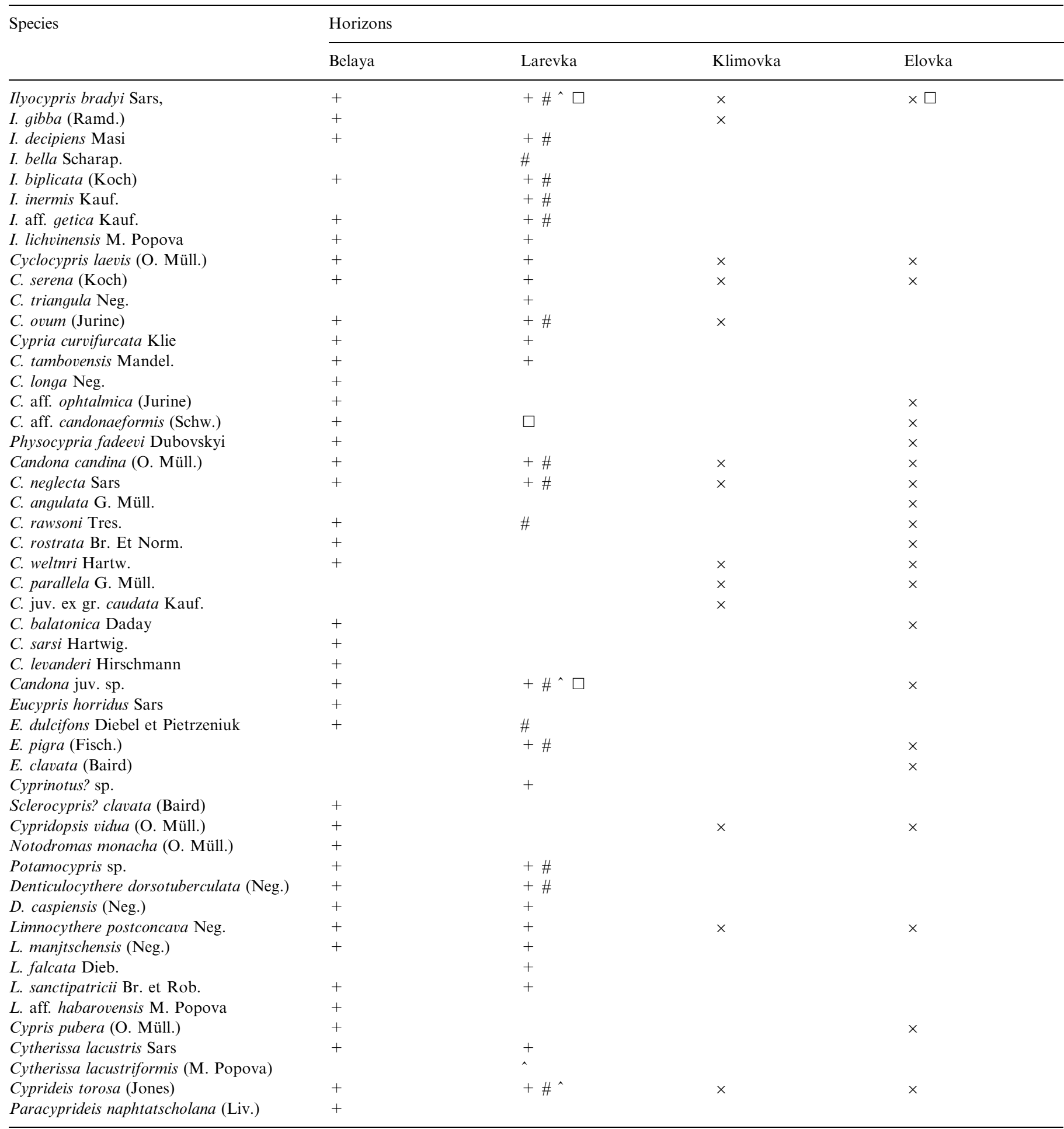

Legend: +, Gornova II; \#, Chui-AtasevoV; ^, Chatra 13; $\square$, Minzitarovo; × , Sultanaevo.

Fraxinus, Betula, Chenopodiaceae, Poaceae, herbs and Artemisia (Voevodskoe site). The contemporaneous climate was moderately warm (Gornova site).

The age of Belaya Horizon is not certain. The palynological characteristics do not definitely indicate that it is definitely of Likhvin Interglacial age. The majority of the mammal species found in these deposits belong to the Chozarian mammal assemblage. The key species characteristic of the Singilian (= Gunkovian) mammal assemblage, such as Arvicola cantianus, were not found in Belaya. 
Table 4

Molluscs from the Middle Neopleistocene deposits

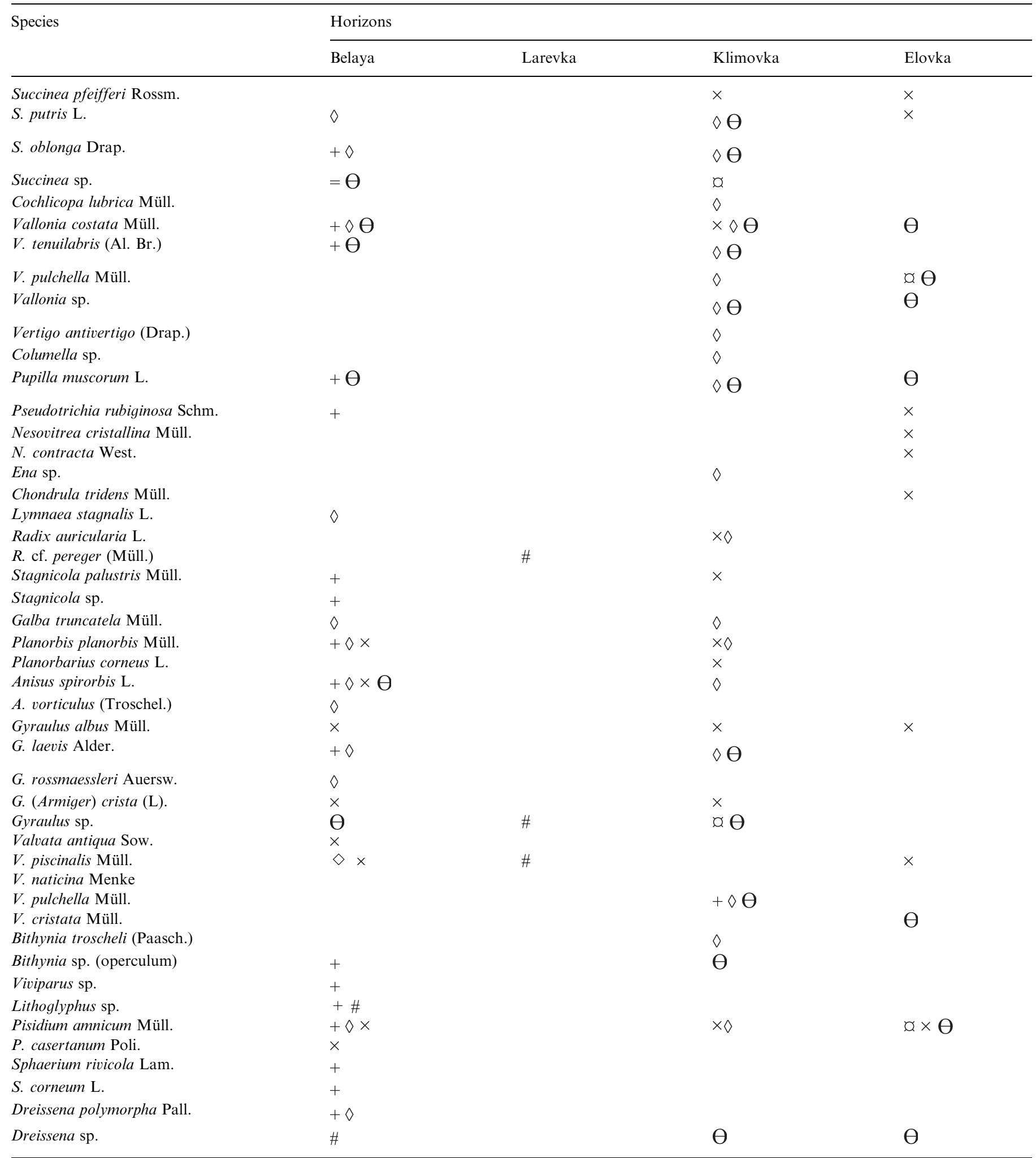

Legend: +, Gornova II and III; $\diamond$, климовка III; × Sultanaevo; \#, Chui-Atasevo V; đo, Gurovka; =, Voevodskoe; $\Theta$, Gruzdevka. 
So it is possible that this horizon possible could be correlated with a later interval, or related to the end of Likhvin Interglacial.

\subsection{Larevka Horizon}

This horizon was defined and described by V.L. Yakchemovich in 1983. The deposits described from the stratotype sections at Larevka (borehole 129) and Golovnoi (borehole 133) are located to the south of Lake Chusovskoje. The horizon was named after the Larevka River and Larevka village (Northern Fore-Urals, Perm district).

The characteristics of this Horizon on the Southern Fore-Urals are that the deposits have been intensively eroded and are known only from within the Belaya river valley. The Horizon is represented by lacustrine and slope deposits of periglacial type, including clay, loam, sandy loam, sand and gravel. Traces of frost penetration have been observed at the Gornova II site. The total thickness of the unit is $0.4-5.6 \mathrm{~m}$. The deposits overlie the Belaya Horizon and are, in turn, overlain by Klimovka Horizon or Upper Neopleistocene sediments.

The key sites for this unit in the Southern Fore-Urals are Starye Tukmakly, Chui-Atasevo I, III, V and Sultanaevo (bore pits I, 2, borehole 1, outcrop 108; Voevodskoe; Klimovka II; Gornova II; Minzitarovo; Chatra). The parastratotype sites: Gornova II (beds 13-24; Yakchemovich et al., 1987 or beds 4, 5 Danukalova et al., 2002) and Sultanaevo, outcrop 107 (beds 11-13) (Yakchemovich et al., 1983, pp. 4-36).

Ostracod assemblages recovered from the unit consist of 30 species and 11 genera (526 determined specimens: Table 3). The assemblage of cold-resistant species was found from the Gornova II locality (418 specimens). The assemblage from the Chui-AtasevoV locality (85 specimens) consists of a small number of Ilyocypris bradyi Sars, I. decipiens Masi, I. bella Scharap., I. biplicata (Koch) and numerous stenothermic cold-resistant $I$. inermis Kauf., I. aff. getica Masi, Cyclocypris ovum (Jurine), Candona neglecta Sars, Candona juv., Eucypris dulcifons Dieb. et Pietr. and Denticulocythere dorsotuberculata (Neg.). Candona candina, C. rawsoni, Eucypris pigra, Potamocypris sp. and Cyprideis torosa (Jones). Some of the Limnocythere are cold-resistant species from the freshwater complexes (Popova-Lvova, 1988; Danukalova et al., 2002). Shells of Ilyocypris bradyi Sars, Candona sp., Cytherissa lacustriformis (M. Popova), Cyprideis torosa (Jones) are known from the Chatra 13 locality (Yakchemovich et al., 2000), whilst 9 ostracod shells are known from the Minzitarovo locality-Ilyocypris bradyi Sars, Cypria candonaeformis (Schw.) and Candona sp., together with some redeposited Pliocene species (Yakchemovich et al., 1985).

The molluscan assemblages from the Larevka Horizon consist of 3 species and 3 genera ( 25 determined specimens) of freshwater taxa from the Chui-Atasevo V locality: Radix cf. pereger (Müll.), Gyraulus sp. and Valvata piscinalis (Müll.) (described by E.M. Morozova, unpublished).

The cold-steppe vegetational communities from the beginning of the Larevka time, dominated by large numbers of Chenopodiaceae, changed gradually to associations that indicate an increased role of Picea taiga forest, with Pinus, Tilia and Ulmus (Gornova locality), under cold climatic conditions. This horizon could be correlated with the Borisoglebsk cold interval or even with later cold interval (Orchik cooling), described from the Russian Plain (Table 2) (Breslav et al., 1992, Velichko et al., 1992).

\subsection{Klimovka Horizon}

This is a new name for this unit, which was previously termed the Gornova Horizon. A.M. Nigmatullina (unpublished) first described the stratotype site for this unit in 1989, then it was redescribed by G.A. Danukalova and A.G. Yakovlev in 2000 (Danukalova and Yakovlev, 2004). The horizon is named from the village Klimovka in the Meleuz region of the Bashkortostan Republic.

The deposits of this horizon formed the middle-lower part of the third river terrace, above the floodplain, and are fluvial gravels (Klimovka II). Palaeosols from that time include the 'second' Sultanaevo soil (Sultanaevo, outcrop 107), the 'first' Voevodskoe soil and the 'second' ChuiAtasevo soil (Chui-Atasevo III). Their thickness is up to $1.5 \mathrm{~m}$. The deposits occur on the eroded surfaces of the underlying Larevka Horizon and are overlain by sediments of the Elovka Horizon or of the Upper Neopleistocene.

Key sites for the Klimovka Horizon include Sultanaevo (outcrop 107); Krasnyi Yar; Voevodskoe; Chui-Atasevo III; Gruzdevka; Klimovka II, III and Chatra. The stratotype site is Klimovka II, bed 5 (Danukalova and Yakovlev, 2004, pp. 232-235) and parastratotype site is Sultanaevo, bore pit two, beds 9-12a (Yakchemovich et al., 1983, pp. 4-43).

The ostracod assemblages found from Sultanaevo locality consist of 13 species and 6 genera (68 determined specimens: Table 3; Yakchemovich et al., 1983). The molluscan assemblage from the unit consists of 25 species and 19 genera (164 determined specimens: Table 4). Both freshwater and terrestrial molluscs were found from the deposits at Sultanaevo (Yakchemovich et al., 1983), Gruzdevka (45 specimens) and Klimovka III site (87 specimens). Two shells of Succinea sp. and Gyraulus sp. are known from Gurovka locality (Sydnev, 1988).

Small-mammals were investigated from two sites in this unit-Krasnyi Yar and Klimovka II. The small-mammal assemblage from the Krasnyi Yar locality (bed 4) consists of 13 species and 12 genera (3018 determined specimens: Table 5). V.P. Suchov and A.G. Yakovlev discovered the small-mammal remains from the deposits of the Krasnyi Yar locality (bed 4) in 1983. These sediments could be correlated with the cooling in the middle part of Klimovka time. Numerous bones were collected from the lower part of the periglacial alluvium by A.G. Yakovlev in 1984-1986 
Table 5

Mammals from the Middle Neopleistocene deposits

\begin{tabular}{|c|c|c|c|c|}
\hline \multirow[t]{3}{*}{ Species } & \multicolumn{4}{|c|}{ Horizons } \\
\hline & \multirow[t]{2}{*}{ Belaya } & \multicolumn{2}{|l|}{ Klimovka } & \multirow[t]{2}{*}{ Elovka } \\
\hline & & $\begin{array}{l}\text { Cold Interval (the } \\
\text { middle part) }\end{array}$ & $\begin{array}{l}\text { Warming (the end of the } \\
\text { period) }\end{array}$ & \\
\hline Ochotona sp. & & ○ & $\Delta \theta$ & \\
\hline Spermophilus sp. & & O & $\theta$ & \\
\hline Marmota sp. & & & $\diamond$ & \\
\hline Marmota aff. bobac & & 0 & & \\
\hline Sicista $\mathrm{sp}$ & & & $\diamond$ & \\
\hline Allactaga sp. & & 0 & & \\
\hline Alactagulus sp. & & ○ & $\diamond$ & \\
\hline Ellobius sp. & & & $\diamond$ & \\
\hline Allocricetulus eversmanni & & ○ & & \\
\hline Cricetulus sp. & & ○ & $\diamond$ & \\
\hline Clethrionomys cf. glareolus & & & $\diamond$ & \\
\hline Clethrionomys sp. & + & & $\Theta$ & \\
\hline Lagurus lagurus & & ○ & $\diamond \theta$ & \\
\hline Lagurus sp. & + & & & \\
\hline Eolagurus luteus & & ○ & $\diamond$ & \\
\hline Eolagurus sp. & + & & & \\
\hline Arvicola cf. chosaricus & & O & & \\
\hline Arvicola $\mathrm{sp}$ & & & $\diamond$ & \\
\hline Microtus (Stenocranius) gregalis & & ○ & $\Delta \theta$ & \\
\hline Microtus oeconomus & + & & $\diamond \theta$ & \\
\hline Microtus ex gr. Oeconomus & & O & & \\
\hline Microtus ex gr. arvalis-agrestis & & & $\diamond$ & \\
\hline Microtus ex gr. Arvalis & & & $\Theta$ & \\
\hline Microtus sp. & + & ○ & $\Delta \theta$ & \\
\hline Mustela nivalis & & ○ & & \\
\hline Mammuthus chosaricus & $+\times \Delta$ & & & \\
\hline Mammuthus sp. & + & & & \\
\hline Equus caballus fossilis & + & & & \\
\hline Equus sp. & $+\Delta$ & & & \\
\hline Cervus sp. & $\Delta$ & & & \\
\hline Bison priscus gigas & + & & & \\
\hline Bison sp. & $+\Delta$ & & & \\
\hline Camelus sp. & + & & & \\
\hline
\end{tabular}

Legend: +, Gornova III, ×, Sultanaevo; $\Delta$, Starye Tukmakly; ○, Krasnyi Yar; $\diamond$, Klimovka II; $\Theta$, Gruzdevka.

(Yakchemovich et al., 1987) including Ochotona sp. (11), Spermophilus sp. (15), Marmota aff. bobac Müll. (44), Allactaga sp. (1), Alactagulus sp. (11), Allocricetulus eversmanni Brandt (1), Cricetulus sp. (2), Lagurus lagurus Pall. (2369, including $587 \mathrm{M}_{1}$ ), Eolagurus luteus Eversm. (156, including $39 \mathrm{M}_{1}$ ), Arvicola cf. chosaricus Alexandrova (9, including $\left.1 \mathrm{M}_{1}\right)$, Microtus gregalis Pall. (77 $\left.\mathrm{M}_{1}\right)$, Microtus ex gr. oeconomus Pall. $\left(9 \mathrm{M}_{1}\right)$, Microtus sp. (3 11 ) and Mustela nivalis L. (2). The age of the fauna has been determined on the basis of the water-vole tooth morphology. Enamel differentiation of the molars of the water voles is close to isometric. The average significance of the coefficient of the enamel differentiation for the water vole teeth is 1.14 (Yakovlev, 1988). These remains are of
Arvicola cf. chosaricus, which characterise the first (?) Kaluga glaciation (Shik, 2004) of the Middle Neopleistocene. The significant part of the primitive morphotypes of the $\mathrm{M}_{1}$ of the Lagurus lagurus and Microtus gregalis is also an indirect evidence of the age of the remains (Tables 5 and 6). This fauna is younger than that from Chernyi Yar, the stratotype of the Chozarian mammal complex (Alexandrova, 1976; Markova, 1982, 2004a, b) and could be correlated with the cooling in the middle part of the Klimovka time. The absence of tundra species (lemmings) is a peculiarity of the Krasnyi Yar fauna.

The small-mammal assemblage from the Klimovka unit consists of 17 species and 13 genera (565 determined specimens: Table 5). At the Klimovka II locality bone 
material (332 specimens) is concentrated mainly in the upper part of Klimovka deposits and includes Ochotona sp. (18), Marmota sp. (1), Sicista sp. (2), Alactagulus sp. (4), Ellobius sp. (11), Cricetulus sp. (2), Clethrionomys cf. glareolus Schreb. (5, including $1 \mathrm{M}_{1}$ ), Lagurus lagurus Pall. (89, including $20 \mathrm{M}_{1}$ ), Eolagurus luteus Pall. (28,

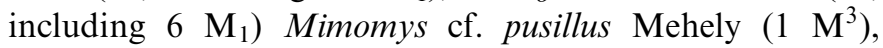
Arvicola sp. (1), Microtus gregalis Pall. (32 $\left.\mathrm{M}_{1}\right)$, M. oeconomus Pall. ( $\left.3 \mathrm{M}_{1}\right), M$. ex gr. arvalis-agrestis $\left(2 \mathrm{M}_{1}\right), M$. ex gr. malei Hinton $\left(1 \mathrm{M}_{1}\right)$ and Microtus sp. (132). The material is well preserved. Post-cranial bones, lower mandibles without teeth and teeth were all found together. The material is dirty-white and to light-yellow in colour. The $\mathrm{M}^{3}$ of the tooth-rooted voles of the genus the Mimomys and $\mathrm{M}_{1}$ of Microtus ex gr. malei Hinton have been reworked from the lower Horizons. The species composition of the Klimovka fauna is close to that of the Gruzdevka fauna. It is possible that the Klimovka fauna is older than that from Gruzdevka but it is younger than the fauna from Krasnyi Yar. This is based on the morphotype distribution of the $\mathrm{M}_{1}$ of Lagurus lagurus Pall. and Microtus gregalis Pall. (Tables 6 and 7). This fauna is assigned to the Klimovka (Gorkinsky) interglacial (Tables 1, 2). The Gruzdevka locality was described by A.G. Yakovlev in 1986 and later was redescribed by G.A. Danukalova in 2005. A.G. Yakovlev found small-mammal material (233 specimens) from the Klimovka fluvial deposits that included Ochotona sp. (4), Spermophilus sp. (1), Clethrionomys sp. (17, including $1 \mathrm{M}_{1}$ ), Lagurus lagurus Pall. (111, including $28 \mathrm{M}_{1}$ ) Microtus cf. oeconomus Pall. (1 $\left.\mathrm{M}_{1}\right)$, M. gregalis Pall. $\left(21 \mathrm{M}_{1}\right), M$. ex gr. arvalis Pall. $\left(1 \mathrm{M}_{1}\right)$ and Microtus sp. (77). These materials are poorly preserved and are white, yellow and light-brown in colour. The bones are sometimes dark in colour. The preservation of the molars is a result of redeposition in the secondary fluvial localities. The Gruzdevka fauna is younger than the mammal associations from the Krasnyi Yar (Larevka period) and Klimovka localities, on the basis of the morphotypes of $\mathrm{M}_{1}$ of Lagurus lagurus Pall. and Microtus gregalis Pall. (Tables 6 and 7). The Gruzdevka fauna dates from the second half of the Middle Neopleistocene (probably Gruzdevka and Klimovka faunas could be correlated with the warming in the end of the Klimovka time Shik, 2004).

Spore and pollen remains are common in these sediments. They include Poaceae, herbs, Pinus, and Picea (Klimovka II, Voevodskoe, Chui-Atasevo), and indicate that forest-steppe vegetation was widespread at the beginning of this interval, and this was later followed by the establishment of Pinus-Betula forests. Broad-leaved trees appeared in the forests in the middle of Klimovka interglacial. The role of the open woodlands increased towards the end of this interval (Sultanaevo, Chatra, Yakchemovich et al., 1983). The climate was moderately warm during this phase.

\subsection{Elovka Horizon}

This horizon was distinguished and described by V.L. Yakchemovich in 1983. This author described deposits from the stratotype section at Elovka (borehole 116) and Larevka (borehole 129). It was named after the Elovka River (Northern Fore-Urals, Perm district).

The deposits of this horizon form the upper part of the third terrace above the floodplain and comprise lacustrineslope loam and sandy loam of the periglacial type (Minzitarovo, Chui-Atasevo III). They are 0.3-4.1 m thick. The deposits occur on the surfaces of the Klimovka Horizon and are overlain by loam and gravel of the Kushnarenkovo unit or by Tabulda sediments dating from

Table 6

Principal morphotypes of $\mathrm{M}_{1}$ of Lagurus lagurus Pall. from Middle Neopleistocene sites of the Southern Fore-Urals (\%)

\begin{tabular}{lllll}
\hline Sites & \multicolumn{2}{l}{ Morphotypes (\%) } & & \\
\cline { 2 - 5 } & $n$ & “transiens” & "transies - lagurus” & "lagurus" \\
\hline Krasnyi Yar & 519 & 18,1 & 41,4 & 40,5 \\
Klimovka & 16 & 18,75 & 31,5 & 49,75 \\
Gruzdevka & 18 & 16,6 & 16,65 & 66,75 \\
\hline
\end{tabular}

Table 7

Principal morphotypes of $\mathrm{M}_{1}$ of Microtus gregalis Pall. from the Middle Neopleistocene sites of the Southern Fore-Urals (\%)

\begin{tabular}{lllll}
\hline Sites & \multicolumn{2}{l}{ Morphotypes (\%) } & & \\
\cline { 2 - 5 } & $n$ & "gregalis" & "gregalis - arvalis" & "arvalis" \\
\hline Krasnyi Yar & 77 & 59,7 & 27,3 & 13 \\
Klimovka & 27 & 37,1 & 44,4 & 18,5 \\
Gruzdevka & 21 & 38,2 & 32,4 & 29,4 \\
\hline
\end{tabular}


the Upper Neopleistocene (a unit of the Russian stratigraphic scheme, equivalent to the Late Pleistocene Subseries, 0.135-0.10 Ma; Danukalova et al., 2002; Shik, 2004).

The key sites at which the unit is found include Klimovka II; Voevodskoe; Sultanaevo, bore pits 2, 3, outcrop 107; Chui-Atasevo III; Minzitarovo; Gruzdevka and Chatra. The parastratotype site is Sultanaevo, outcrop 107, beds 7-8 (Yakchemovich et al., 1983, pp. 36-43).

Ostracod assemblage present in this unit consists of 20 species and 10 genera (47 determined specimens: Table 3 ). Ostracods (45 specimens) from the freshwater sediments at the Sultanaevo locality include Candona juv. ex gr. neglecta, C. candida, C. balatonica, C. rawsoni and Eucypris pigra which are cold-resistant elements (Yakchemovich et al., 1983). Two shells of the ostracod Ilyocypris bradyi Sars are known from the Minzitarovo site (Yakchemovich et al., 1985).

The Mollusca assemblages consist of 14 species and 11 genera (55 determined specimens: Table 4). Throughout mollusc shells are rare. Both terrestrial and freshwater molluscs have been identified from the Sultanaevo site (22 specimens:Yakchemovich et al., 1983) and from the Gruzdevka site (31 specimens), but only 2 specimens were found from Gurovka (Sydnev, 1988).

Palynological remains are also rare (Voevodskoe site); the pollen are dominated by herbs, Chenopodiaceae, Poaceae and Artemisia. The pollen of the trees Pinus, Betula and Picea also occur (e.g. at Sultanaevo and Chatra). The climate indicated by these taxa was cold during the beginning and middle part of the period.

\section{Conclusions}

The deposits of the Middle Neopleistocene (Late Middle Pleistocene) are only represented in the local areas owing to later erosion. These processes became active from the beginning of the Belaya time (Yakchemovich et al., 1981; Table 1) when uplift took place in the Urals (Yakchemovich et al., 1981) and the Singil regression began on the Caspian Sea basin territory (Yakchemovich et al., 1981; Shik, 2004; Table 1). Fluvial deposits of that time occurred in the overdeepened valleys which formed in accordance with the water level of the Caspian basin (base of erosion) (Gornova, Sultanaevo, Mynzytarovo, Krasnyi Yar). In the Fore-Urals region, early Middle Neopleistocene deposits (Belaya Horizon) can be studied in the boreholes or in the lower parts of the fluvial terrace sequences that now occur above the floodplain where local uplift occurred and along tributaries. In the Urals these deposits can be found in the lower parts of the terrace sequences. Towards the end of the Belaya period, erosional process decreased and lacustrine and floodplain deposits formed. Soil was formed on the subhorizontal surfaces (e.g. the first Chui-Atasevo soil, the first Sultanaevo soil), under a warm climate. The plant zonation of that period can be observed in mountainswoodland of coniferous trees occurred on the mountain tops and mixed woodland occupied the valleys. In the northern parts of the region forests existed, whilst in the southern parts forest-steppe grew. Swamps formed in the depressions. Rich associations of abundant ostracods and molluscs are known from the localities Gornova, Sultanaevo, Chui-Atasevo and Gurovka. The mammals present belong to the Chozar mammal assemblage from Gornova, Sultanaevo and Starye Tukmakly. The Belaya deposits could possibly be correlated with the end of Likhvin Interglacial or may date from a slightly later time (Table 1).

The subsequent Larevka cold period is correlated with Kaluga period of the Russian Plain, when the Borisoglebsk loess Horizon was deposited (Table 2). Erosion processes during this time became weaker. Floodplain sediments accumulated in the river valleys, slope-lacustrine deposits accumulated in the freshwater lakes (e.g. at Krasnyi Yar, Klimovka, Sultanaevo, Voevodskoe, Minzitarovo and Chui-Atasevo). The region was unglaciated at this time, although small corrie glaciers did form in mountains above $2000 \mathrm{~m}$. Processes of frost weathering were active in mountains and stone rivers (block-train) were formed. Forest-tundra and periglacial steppe vegetation dominated the landscape with tundra on the mountain tops. This vegetation was mainly represented by the periglacial steppes or by the sparse growth of coniferous trees. Faunal finds are rare from this time, although cold-resistant ostracods (Chui-Atasevo V, Gornova II and Minzitarovo) and molluscs (Chui-Atasevo V) are known.

A new erosional cycle began during the following Klimovka period (Yakchemovich et al., 1981). Because of the lowering of base level of erosion, snow thaw and increased discharge of waters in streams and probably slow tectonic uplift of the territory (Yakchemovich et al., 1981). Fluvial deposits from this period formed the middle-lower parts of the III terraces above the floodplain and were often overlain by the Belaya alluvium. Soil was formed on the watersheds (e.g. the second Chui-Atasevo soil, the second Sultanaevo soil, and the first Voevodskoe soil). Palaeontological data from Klimovka unit allow two different climatic intervals to be identified. The first is characterised by the palaeontological data which indicates periglacial climatic conditions of the cooling in the middle part of the Klimovka time. This interval probably could be correlated with the Orchik Cold Interval of the Russian Plain or with the beginning of the Dnieper glaciation. Taiga and mixed forest vegetation spread later, representing the warming in the end of the Klimovka time. This event could be correlated with the Romny Warming of the Russian Plain (Table 2).

The subsequent Elovka event is correlated with the Moscow glaciation. Mountain landscapes remained unchanged during this period, but slope processes were intensified. The fluvial sediments, which formed the upper parts of the III terrace deposits, were laid down (Sultanaevo, Minzitarovo and Chui-Atasevo). The frost basins covered significant areas of the Urals and Fore- Urals. Open treeless landscapes were dominant, only small forests of Picea, Pinus and Betula trees were able to grow on valley 
slopes and in the mountains. Rare ostracods and molluscs occurred in the aquatic deposits. The small mammals from these deposits belong to the Chozarian complex.

Thus, the undergoing studies allow the differentiation of the principal late Middle Pleistocene Horizons in the South Urals regions. The rich palaeontological materials allowed the reconstruction of the main environmental characteristics. However, there still remain many questions concerning the age of the horizons distinguished. It is hoped that future studies will improve the definition of the dates and duration of the horizons that occur in this critical region.

\section{Acknowledgements}

This research was carried out under the partial financial support of the Russian Foundation of Fundamental Investigations (RFFI); Grant no. 03-05-64693. The authors would like to thank Philip Leonard Gibbard (Cambridge, UK) for help with the English translation and Anastasia Markova (Institute of Geography, Moscow, Russia) for consultation and help during the preparation of the paper.

\section{References}

Agadjanian, A.K., 1987. Collection and study of remains of small mammals. In: Kaplin, P.A. (Ed.), The Investigations of the Complex Biostratigraphy. Moscow State University Press, Moscow, pp. 27-58 (in Russian).

Alexandrova, L.P., 1976. Anthropogene Rodents of the European Part of USSR. Nauka-Press, Moscow, 98pp (Transactions of Geological Institute of the Academy of Sciences of USSR. Issue 291) (in Russian).

Breslav, S.L., Valueva, M.N., Velichko, A.A., Iosifova, Yu.I., Krasnenkov, R.V., Morozova, T.D., Udartsev, V.P., Shik, S.M., 1992. Stratigraphic scheme of the Quaternary deposits in the central parts of Eastern Europe. In: Stratigraphy and Palaeogeography of the Quaternary of the Eastern Europe. Institute of Geography Russian Academy of Sciences Press, Moscow, pp. 8-36 (in Russian).

Danukalova, G.A., Yakovlev, A.G., 2004. New data on the stratigraphy of the Middle Neopleistocene deposits of the Southern Urals region. In: Yshkin, N.P. (Ed.), Geology and Mineral Resources of the European Northeast of Russia, vol. III. Sedimentology, Evolution of the Sedimentary Basins. Oil and Gas Geology Stratigraphy. Palaeontology. Materials of the XIV Geological Congress of the Komi Republic. Geoprint-Press, Syktyvkar, pp. 232-235 (in Russian)

Danukalova, G.A., Yakovlev, A.G., Puchkov, V.N., Danukalov, K.N., Agadjanian, A.K., Van Kolfschoten, Th., Morozova, E.M., Eremeev, A.A., 2002. Excursion Guide of the INQUA SEQS-2002 Conference, 30 June - 7 July, 2002, Ufa, Russia (INQUA SEQS-2002 Conference "The Upper Pliocene-Pleistocene of the Southern Urals Region and its Significance for Correlation of Eastern and Western Parts of Europe"). Dauria-Press, Ufa, 139pp.

Gibbard, P.L., Boreham, S., Cohen, K.M., Moscariello, A., 2004. Global Chronostratigraphical correlation table for the last 2.7 million years. Boreas 34, unpaginated.

Gittenberger, E., Janssen, A.W., 1998. Nederlandse Fauna 2, De Nederlandse Zoetwatermollusken. Recente en fossiele weekdieren uit zoet en brak water. Nationaal Natuurhistorisch museum Naturalis KNNV uitgeverij, European Invertebrate Survey, Netherlands, 288pp.

Grichuk, V.P., Zaklinskaya, E.D., 1948. The analysis of fossil pollen and spore and using these data in paleogeography. GeographGIZ Press, Moscow, 220pp (in Russian).

Gromov, V.I., Baranova, G.I., 1981. Catalogue of mammals of the USSR (Pliocene-recent). Nauka-Press, Leningrad, 456pp (in Russian).
Gromov, V.I., Erbaeva, M.A., 1995. The Mammals of Russia and Adjacent Territories. Lagomorphs and Rodents. Zoological Institute Russian Academy of Sciences Press, Sankt Petersburg, 522pp (Transactions of the Zoological institute, Issue 167) (in Russian).

Guslitcer, B.I., 1979. In Search of Small Mammal Fossil Remains. Academy of Sciences of USSR Press, Syktyvkar, pp. 1-39 (in Russian).

Kerney, M.P., Cameron, R.A.D., 1999. Guide des Escargots et limaces d'Europe. Delachaux et Niestle S.A., Lausanne, 370pp.

Likharev, I.M., Rammelmeier, E.S., 1952. Land molluscs of the fauna of the USSR. Academy of Sciences of USSR Press, Leningrad, Moscow, 512pp (Transactions of the Zoological Institute USSR. vol. 43) (in Russian).

Markova, A.K., 1982. Pleistocene rodents of Russian plain (their significance for the palaeogeography and stratigraphy). Nauka-Press, Moscow, 186pp (in Russian).

Markova, A.K., 2004a. Reconstruction of the palaeolandscapes of the Likhvin interglaciation according to small mammal faunas of the Eastern Europe. Izvestija, Russian Academy of Natural Sciences, Series Geographic 2, 39-51.

Markova, A.K., 2004b. Pleistocene microtheriofauna of Eastern Europe. In: Geography, Society and Environment, vol. 1. Structure, Dynamics and Evolution of the Native Systems. Gorodets, Moscow, pp. 583-598.

Pokrovskaja, I.M., 1950. Palynologic analysis. Geologic Literature-Press, Moscow, pp. 1-571 (in Russian).

Popova-Lvova, M.G., 1988. Ostracods from type localities Chui-Atasevo and Gornova of the Bashkirian Fore-Urals. In: Kamaletdinov, M.A., Yakchemovitch, V.L. (Eds.), Some Questions of the Biostratigraphy, Palaeomagnetizm and Tectonic of the Cenozoic of the Fore-Urals. Bashkir Centre of Academy of Sciences USSR Press, Ufa, pp. 24-60 (in Russian).

Rekovets, L.I., 1994. Small Mammals of Anthropogene of the South of Eastern Europe. Naukova Dumka Press, Kiev, 371pp (in Russian).

Shik, S.M., 2004. About project of the regional stratigraphic scheme of the Quaternary of the European Russia. In: Leonov, J.G. (Ed.), Ecology of the Anthropogene and the Present: Nature and a Man. Collection of the Scientific Reports to the International Conference (VolgogradAstrakhan-Volgograd, September 24-27, 2004). Gumanistica-Press, Sankt Peterburg, pp. 21-26 (in Russian).

Shik, S.M., Borisov, B.A., Zarrina, E.P., 2002. About the project of the interregional stratigraphic scheme of the Neopleistocene of the EastEuropean platform and about the perfection of the regional stratigraphic schemes. In: Kozlov, V.B. (Ed.), Materials of the Third All Russian Quaternary Conference, vol. 2. Oikumena-Press, Smolensk, pp. 125-129 (in Russian).

Shileiko, A.A., 1978. Land molluscs of the Helicoidea. Nauka-Press, Leningrad (Fauna of the USSR. Mollusca. vol. 3, Issue 6), 384pp (in Russian).

Shileiko, A.A., 1984. Land molluses of the Pupillina (Gastropoda, Pulmonata, Geophila). Nauka-Press, Leningrad, pp. 1-399 (Fauna of the USSR. Mollusca, vol. 3, Issue 3) (in Russian).

Shileiko, A.A., Likharev, I.M., 1986. Terrestrial molluscs of the family Succineidae of the fauna of the USSR. In: Archives of Zoological Museum of Moscow State University, vol. XXIV. Fauna, Systematics and Phylogeny of the Invertebrated Animals, pp. 198-238 (in Russian).

Shokurov, A.P., 1977. Staro-Tukmakly locality of mammal bones in Bashkiria. In: Yakchemovitch, V.L. (Ed.), Results of Biostratigraphic, Lithologic and Phisic Investigations of Pliocene and Pleistocene of the Volga-Urals Area. Bashkir Branch of Academy of Sciences USSR Press, Ufa, pp. 97-102 (in Russian).

Sinitskikh, E.S., 1982. Experiment of elutriation and collection of flora and fauna remains from Pliocene and Pleistocene deposits of Urals. In: Papulov, G.N. (Ed.), Materials to the XI INQUA Congress, Part 2. Ural Scientific Centre of AS USSR Press, Sverdlovsk, pp. 39-43 (in Russian).

Smirnov, N.G., Bolshakov, V.G., Kosintsev, P.A., Panova, N.K., Korobeinikov, Yu.I., Olshvang, V.N., Erokhin, N.G., Bykova, G.V., 1990. Historical Ecology of Animals of the Southern Urals. Urals Branch of Academy of Sciences Press, Sverdlovsk, 245pp (in Russian). 
Stefanovsky, V.V., 1997. Explanatory notes to the Stratigraphic sheme of Quaternary deposits of Urals. In: Explanatory Notes to the Stratigraphic Schemes of Urals. Regional Stratigraphic Commission Press, Ekaterinburg, pp. 97-139 (in Russian).

Sydnev, A.V., 1988. Section of the Likhvin (Belaya) interglacial near village Gurovka, Ufimian region, Bashkir Republic. In: Kamaletdinov, M.A., Yakchemovitch, V.L. (Eds.), Some Questions on the Biostratigraphy, Palaeomagnetism and Tectonic of the Cenozoic of the Fore-Urals. Bashkir Centre of Academy of Sciences USSR Press, Ufa, pp. 61-64 (in Russian).

Turner, Ch., 1998. Volcanic maars, long Quaternary sequences and the work of the INQUA subcommission on European Quaternary stratigraphy. Quaternary International 47/48, 41-49.

Velichko, A.A., Morozova, T.D., Nechaev, V.P., Udartsev, V.P., Tsatskin, A.I., 1992. Problems of the chronostratigraphy and correlation of the loess-palaeosoil formation of the Russian plain. In: Stratigraphy and Palaeogeography of the Quaternary of the Eastern Europe. Institute of Geography Russian Academy of Sciences Press, Moscow, pp. 115-140 (in Russian).

Yakchemovich, V.L., Nemkova, V.K., Suleimanova, F.I., 1981. Pliocene and Pleistocene of the Volga-Urals Region. Nauka-Press, Moscow, 176pp (in Russian).

Yakchemovich, V.L., Nemkova, V.K., Suleimanova, F.I., Popova-Lvova, M.G., Sydnev, A.V., Chepalyga, A.L., 1983. Fauna and Flora of Sultanaevo-Yulushevo. Nauka-Press, Moscow, 152pp (in Russian).
Yakchemovich, V.L., Nemkova, Alimbekova, L.I., Popova-Lvova, M.G., 1985. Results of the Study of Pleistocene Sites in Bashkiria with Elephantidae Remains. Bashkir Branch of Academy of Sciences USSR Press, Ufa, 79pp (in Russian).

Yakchemovich, V.L., Nemkova, V.K., Sydnev, A.V., Suleimanova, F.I., Khabibullina, G.A., Sherbakova, T.I., Yakovlev, A.G., 1987. Pleistocene of the Fore-Urals. Nauka-Press, Moscow, 113pp (in Russian).

Yakchemovich, V.L., Nemkova, V.K., Yakovlev, A.G., 1988. Regional Subdivisions of the New Stratigraphic Scheme of the Pleistocene of the Fore Urals and Some Key Sites. Bashkir Centre of Academy of Sciences USSR Press, Ufa, 65pp (in Russian).

Yakovlev, A.G., 1988. For the history of the genus Arvicola's development in the Pleistocene of the Bashkirian Fore-Urals. In: Kamaletdinov, M.A., Yakchemovitch, V.L. (Eds.), Some Questions of the Biostratigraphy, Palaeomagnetism and Tectonic of the Cenozoic of the Fore-Urals. Bashkir Centre of Academy of Sciences USSR press, Ufa, pp. 17-23 (in Russian).

Zhadin, V.I., 1952. Molluscs of Freshwaters of USSR. Academy of Sciences of USSR Press, Moscow, Leningrad, 376pp. (Transactions of the Zoological institute AC USSR. vol. 46) (in Russian).

Zhamoida, A.I., Kovalevsky, O.P., Koren', T.N., Margulis, L.S., Predtechensky, N.N., Rublev, A.G., Semikhatov, M.A., Khramov, A.N., Shkatova, V.K., 2000. Supplements to the Stratigraphic Code of Russia. VSEGEI Press, St. Petersburg, 112pp (in Russian). 